\title{
Gordonia defluvii sp. nov., an actinomycete isolated from activated sludge foam
}

Correspondence

Michael Goodfellow

m.goodfellow@ncl.ac.uk

\author{
Jacques A. Soddell, ${ }^{1}$ Fiona M. Stainsby, ${ }^{2} \uparrow$ Kathryn L. Eales, ${ }^{1}$ \\ Robert J. Seviour ${ }^{1}$ and Michael Goodfellow ${ }^{2}$ \\ ${ }^{1}$ Biotechnology Research Centre, La Trobe University, Bendigo, Victoria 3552, Australia \\ ${ }^{2}$ Division of Biology, University of Newcastle, Newcastle upon Tyne NE1 7RU, UK
}

\begin{abstract}
Three strains of non-motile, Gram-positive, filamentous actinomycetes, isolates $\mathrm{J} 4^{\top}$, J5 and J59, initially recognized microscopically in activated sludge foam by their distinctive branching patterns, were isolated by micromanipulation. The taxonomic positions of the isolates were determined using a polyphasic approach. Almost-complete 16S rRNA gene sequences of the isolates were aligned with corresponding sequences of representatives of the suborder Corynebacterineae and phylogenetic trees were inferred using three tree-making algorithms. The organisms formed a distinct phyletic line in the Gordonia 16S rRNA gene tree. The three isolates showed 16S rRNA gene sequence similarities within the range $96 \cdot 9-97 \cdot 2 \%$ with their nearest phylogenetic neighbours, namely Gordonia bronchialis DSM $43247^{\top}$ and Gordonia terrae DSM $43249^{\top}$. Strain $\mathrm{J} 4^{\top}$ was shown to have a chemotaxonomic profile typical of the genus Gordonia and was readily distinguished from representatives of the genus on the basis of Curie-point pyrolysis mass spectrometric data. The isolates shared nearly identical phenotypic profiles that distinguished them from representatives of the most closely related Gordonia species. It is evident from the genotypic and phenotypic data that the three isolates belong to a novel Gordonia species. The name proposed for this taxon is Gordonia defluvii sp. nov.; the type strain is $\mathrm{J}^{\top}$ (=DSM $44981^{\top}=$ NCIMB $14149^{\top}$ ).
\end{abstract}

Most activated sludge systems suffer intermittently from the serious operational disorder known as foaming or scumming, whereby a stable foam or scum develops on the surface of aeration tanks (Soddell, 1999). The reasons for the appearance of such foams are not clear, but their stable nature is imparted by the presence of large numbers of bacteria in the foam layer. In many cases, these foamassociated bacteria are mycolic acid-containing actinomycetes that belong to the suborder Corynebacterineae Stackebrandt et al. 1997. It is generally accepted that mycolic acids render cells sufficiently hydrophobic to allow them to accumulate on the surfaces of aeration tanks (Seviour \& Blackall, 1999).

Initially, Nocardia amarae (now Gordonia amarae Klatte et al. 1994) was implicated in foaming (Lechevalier \& Lechevalier, 1974), but it is apparent from culture-dependent and -independent approaches that diverse populations of mycolic acid-containing actinomycetes are involved. Isolates

tPresent address: School of Life Sciences, Napier University, Edinburgh EH10 5DT, UK.

Abbreviation: PyMS, Curie-point pyrolysis mass spectrometry.

The GenBank/EMBL/DDBJ accession numbers for the 16S rRNA gene sequences of strains $\mathrm{J} 4^{\top}, \mathrm{J} 5$ and $\mathrm{J} 59$ are AY650265AY650267, respectively. representing the genera Millisia (Soddell et al., 2006) and Skermania (Blackall et al., 1989; Chun et al., 1997) have been recovered only from activated sludge foams. Novel species isolated from foams include members of the genera Nocardia (Yamamura et al., 2005) and Tsukamurella (Nam et al., 2003, 2004). However, it is clear that many additional mycolic acidcontaining taxa associated with foam need to be formally described (Soddell \& Seviour, 1998; Stainsby et al., 2002). Such studies are important, as attempts to control the appearance and persistence of foams are unlikely to succeed until the taxonomic diversity and functional roles of the causal organisms are understood (Goodfellow et al., 1996, 1998; Stainsby et al., 2002).

Three isolates with a cellular morphology intermediate between the right-angled branching pattern typical of $G$. amarae Klatte et al. 1994 and the 'pine-tree-like' morphotype of Skermania piniformis Chun et al. 1997 were isolated, by micromanipulation, in Australia from activated sludge foams at Brimbank Park, Victoria (isolates $\mathrm{J}^{\mathrm{T}}$ and J5) and Craigieburn, Victoria (isolate J59), as described by Soddell \& Seviour (1998). These authors considered that the strains might form a novel species on the basis of an extensive numerical taxonomic survey of Skermania and related strains, a proposition underpinned by the results of the present investigation. 
Extraction of chromosomal DNA and PCR amplification and sequencing of 16S rRNA genes of the three isolates were carried out as described previously (Soddell et al., 2006). The resultant $16 \mathrm{~S}$ rRNA gene sequence data were compared with corresponding results taken from the RDP database for representatives of genera classified in the suborder Corynebacterineae. Phylogenetic trees were inferred using the maximum-likelihood (Felsenstein, 1981), maximum-parsimony (Fitch, 1971) and neighbour-joining (Saitou \& Nei, 1987) tree-making algorithms. An evolutionary distance matrix was generated for the neighbourjoining algorithm using the Jukes \& Cantor (1969) distance model. The unrooted tree topologies were evaluated by bootstrap analyses (Felsenstein, 1985) of the neighbourjoining dataset using the SEQBOOT and CONSENSE options from the PHYLIP package (Felsenstein, 1989).

Almost full-length 16S rRNA gene sequences (1519 nucleotides) that corresponded to Escherichia coli positions 271525 were obtained for the three isolates. A comparison of these sequences with those of representatives of the suborder Corynebacterineae showed that the isolates fell within the evolutionary radiation occupied by the genus Gordonia (data not shown). It is evident from Fig. 1 that the isolates form a distinct lineage within the Gordonia 16S rRNA gene tree, a phyletic line that is supported by all of the treemaking algorithms and by a $100 \%$ bootstrap value. The

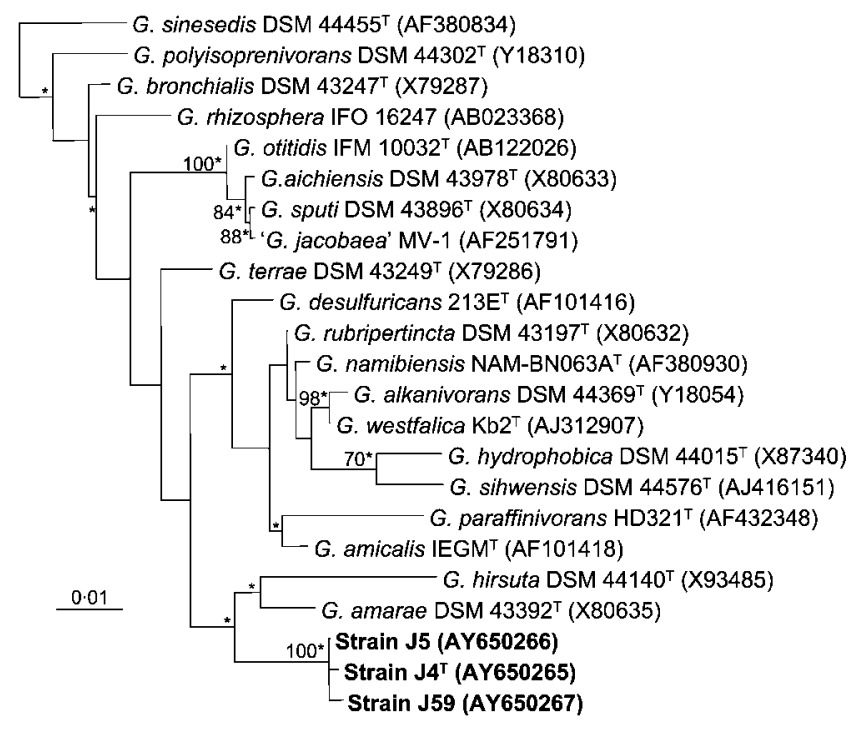

Fig. 1. Neighbour-joining tree based on nearly complete $16 \mathrm{~S}$ rRNA gene sequences showing that isolates $\mathrm{J} 4^{\top}, \mathrm{J} 5$ and $\mathrm{J} 59$ form a distinct phyletic line in the Gordonia 16S rRNA gene tree. Asterisks indicate branches that were also recovered using the maximum-likelihood and maximum-parsimony treemaking algorithms. Numbers at nodes are percentage bootstrap values based on 1000 resampled datasets; only values above $50 \%$ are given. Bar, 0.01 substitutions per nucleotide position. The outgroup strain used to root the tree (not shown) was Turicella otitidis $234 / 92^{\top}$ (GenBank accession no. X73976). isolates shared 16S rRNA gene sequence similarities within the range $99 \cdot 7-99 \cdot 9 \%$, values equivalent to between 2 and 5 nucleotide differences; all but two of the latter were in conserved regions.

It is also apparent from Fig. 1 that the isolates are loosely associated with the type strains of G. amarae $(96 \cdot 2-96 \cdot 4 \%$ similarity) and Gordonia hirsuta (96.0-96.2\% similarity), though these relationships are not supported by a high bootstrap value. Indeed, the isolates are not closely related to any of the Gordonia type strains; their closest relatives are Gordonia bronchialis DSM $43247^{\mathrm{T}}(96 \cdot 9-97 \cdot 2 \%$ similarity) and Gordonia terrae DSM $43249^{\mathrm{T}}(96 \cdot 7-97 \cdot 1 \%$ similarity). Given the low values, it was not necessary to carry out DNADNA pairing experiments between isolate $\mathrm{J}^{\mathrm{T}}$ and its closest phylogenetic neighbours, especially since similarity values well above these levels have been reported between representatives of several species of Gordonia with validly published names. The type strains of Gordonia alkanivorans and Gordonia rubripertincta, for example, share $99 \cdot 1 \%$ $16 \mathrm{~S}$ rRNA gene sequence similarity and have a DNA-DNA relatedness of 52\% (Kummer et al., 1999), a value well below the $70 \%$ cut-off point recommended by Wayne et al. (1987) for the recognition of genomic species.

Strain $\mathrm{J} 4^{\mathrm{T}}$ was the subject of chemotaxonomic studies designed to determine whether it had chemical markers consistent with its classification in the genus Gordonia. Standard methods were used for the extraction and analysis of fatty acids (Midi system; http://www.midi-inc.com), isoprenoid quinones (Minnikin et al., 1984), muramic acid type (Uchida et al., 1999), mycolic acids (Minnikin et al., 1980), polar lipids (Minnikin et al., 1984) and sugars (Schaal, 1985). The isolate contained meso-diaminopimelic acid, arabinose and galactose (wall chemotype IV sensu Lechevalier \& Lechevalier, 1970), N-glycolated muramic acid, dihydrogenated menaquinones with nine isoprene units $\left[\mathrm{MK}-9\left(\mathrm{H}_{2}\right)\right]$ as the predominant isoprenologue with small amounts of MK-8 $\left(\mathrm{H}_{2}\right)$ and diphosphatidylglycerol, phosphatidylglycerol, phosphatidylinositol, phosphatidylinositol dimannosides, phosphatidylethanolamine and an unidentified glycolipid as major polar lipids (phospholipid type 2 sensu Lechevalier et al., 1977). It also contained major proportions of oleic $\left(\mathrm{C}_{18: 1} ; 35 \cdot 2 \%\right.$ of the total fatty acid composition), palmitic $\left(\mathrm{C}_{16: 0} ; 21 \cdot 3 \%\right)$, palmitoleic $\left(\mathrm{C}_{16: 1}\right.$; $17 \cdot 5 \%)$ and tuberculostearic $(9 \cdot 0 \%)$ acids and minor proportions of myristic $(3 \cdot 7 \%)$, margaric $(2 \cdot 7 \%)$, eicosenoic $(2 \cdot 7 \%)$, stearic $(2 \cdot 4 \%)$, heptadecanoic $(2 \cdot 2 \%)$, nonadecenoic $(2 \cdot 1 \%)$ and pentadecyclic $(1 \cdot 2 \%)$ acids. The organism possessed mycolic acids, the methyl esters of which had the same $R_{\mathrm{f}}$ value after thin-layer chromatography as those of G. bronchialis DSM $43247^{\mathrm{T}}$. All of these properties are in line with the assignment of the strain to the genus Gordonia (Goodfellow \& Maldonado, 2006).

The DNA G + C content was determined for strain $\mathrm{J} 4^{\mathrm{T}}$; isolation and purification of the DNA was carried out after Pitcher et al. (1989). The base composition of the resultant DNA preparation was determined using the reversed-phase 


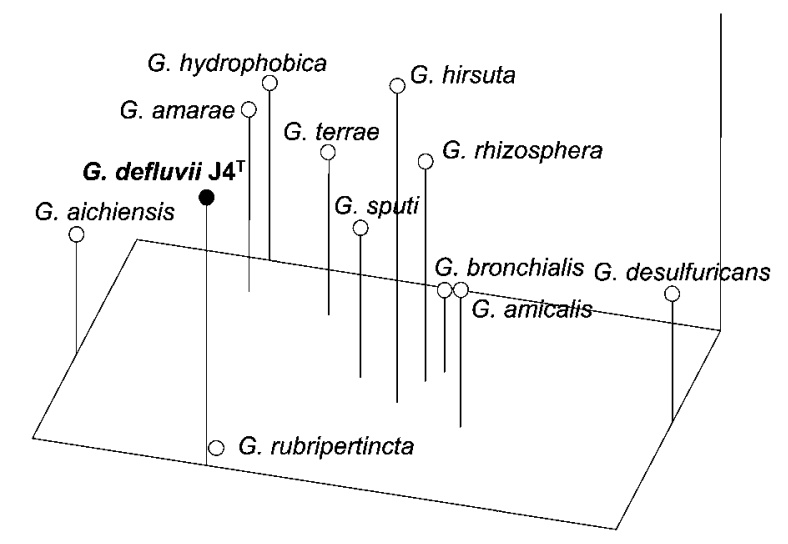

Fig. 2. Three-dimensional ordination diagram generated from PyMS data showing relationships between isolate $\mathrm{J} 4^{\top}$ and the type strains of representative Gordonia species. The plot is based on the first three canonical variates of a principal component-canonical variates analysis that accounted for $93 \%$ of the total variation found between the tested strains.

HPLC procedure described by Tamaoka (1994). The molar $\mathrm{G}+\mathrm{C}$ ratio calculated after Mesbah et al. (1989) was $63 \cdot 1 \mathrm{~mol} \%$.
Curie-point pyrolysis mass spectrometry (PyMS) has been used to good effect to distinguish between closely related organisms, including members of mycolic acid-containing taxa (Goodfellow et al., 1997). A standard PyMS procedure (Goodfellow et al., 1998) was used to determine relationships between isolate $\mathrm{J} 4^{\mathrm{T}}$ and representatives of the genus Gordonia. It is apparent from Fig. 2 that strain $\mathrm{J}^{\mathrm{T}}$ can be readily distinguished from the Gordonia marker strains, including the type strains of G. amarae, G. bronchialis, G. hirsuta and G. terrae. In addition, all three isolates can be distinguished from representatives of these and other phylogenetically close species using a combination of phenotypic properties (Table 1) and by their characteristic micromorphology.

It is clear from the genotypic and phenotypic data that isolates $\mathrm{J} 4^{\mathrm{T}}$, J5 and $\mathrm{J} 59$ merit recognition within a novel species in the genus Gordonia. The name Gordonia defluvii sp. nov. is proposed for this taxon.

\section{Description of Gordonia defluvii sp. nov.}

Gordonia defluvii (de.flu'vi.i. L. gen. n. defluvii of sewage).

The description is taken from this and the earlier study of Soddell \& Seviour (1998). Aerobic, Gram-positive, slightly

Table 1. Phenotypic characteristics that separate isolates $\mathrm{J} 4^{\top}, \mathrm{J} 5$ and $\mathrm{J} 59$ from representatives of closely related Gordonia species

Strains: 1, isolates J4 ${ }^{\mathrm{T}}$, J5 and J59; 2, G. amarae DSM 43392 ${ }^{\mathrm{T}}$; 3, G. bronchialis DSM 43247 $7^{\mathrm{T}}$; , G. hirsuta DSM $44140^{\mathrm{T}}$; 5, G. hydrophobica DSM $44015^{\mathrm{T}}$; 6, G. rubripertincta DSM 43197 ; 7, G. terrae DSM $43249^{\mathrm{T}}$. Data for Gordonia type strains were taken from Maldonado et al. (2003).

\begin{tabular}{|c|c|c|c|c|c|c|c|}
\hline Characteristic & 1 & 2 & 3 & 4 & 5 & 6 & 7 \\
\hline Colour of colony ${ }^{*}$ & $\mathrm{NP}$ & $\mathrm{T} / \mathrm{W}$ & B & $\mathrm{W} / \mathrm{LW}$ & $\mathrm{T} / \mathrm{W}$ & $\mathrm{O} / \mathrm{R}$ & $\mathrm{P} / \mathrm{O}$ \\
\hline \multicolumn{8}{|l|}{ Biochemical tests } \\
\hline Aesculin hydrolysis & - & + & - & + & + & - & + \\
\hline Allantoin hydrolysis & - & + & - & - & + & - & - \\
\hline Nitrate reductase & + & - & + & + & + & - & + \\
\hline Urea hydrolysis & - & + & + & - & - & + & + \\
\hline \multicolumn{8}{|l|}{ Degradation of: $(\%, \mathrm{w} / \mathrm{v})$} \\
\hline Hypoxanthine $(0 \cdot 4)$ & - & + & - & - & + & + & + \\
\hline Starch (1) & - & + & + & + & - & + & + \\
\hline Tributyrin $(0 \cdot 1)$ & + & - & - & - & - & + & - \\
\hline Tween 80 (1) & + & - & - & + & + & - & - \\
\hline Tyrosine $(0 \cdot 5)$ & - & + & - & - & + & - & - \\
\hline Uric acid $(0 \cdot 5)$ & + & + & - & - & + & + & + \\
\hline Xanthine $(0 \cdot 4)$ & - & - & - & - & - & - & + \\
\hline \multicolumn{8}{|c|}{ Growth on sole carbon sources $(\%, w / v)$} \\
\hline Arbutin (1) & + & + & - & + & + & - & - \\
\hline D-Cellobiose (1) & - & - & - & + & - & + & - \\
\hline Glycerol (1) & - & + & + & + & + & + & + \\
\hline$N$-Acetylglucosamine $(0 \cdot 1)$ & + & + & - & + & + & - & - \\
\hline Betaine $(0 \cdot 1)$ & + & - & - & - & - & - & + \\
\hline Sodium fumarate (1) & - & - & + & - & + & + & + \\
\hline
\end{tabular}

${ }^{\star} \mathrm{B}$, Brown; LY, light yellow; NP, non-pigmented; O, orange; $\mathrm{P}$, pink; $\mathrm{R}$, red; $\mathrm{T}, \mathrm{tan} ; \mathrm{W}$, white. 
acid-alcohol-fast, non-motile, non-spore-forming, slowly growing actinomycete that shows acute-angled and rightangled branching. Non-pigmented colonies with filamentous margins and abundant aerial hyphae are formed on glucose-yeast extract agar. Diffusible pigments are not produced. The organism is catalase- and phosphatase-positive but does not produce $m$ - or $p$-nitrophenol oxidases. Esterase lipase $\left(\mathrm{C}_{8}\right)$, leucine aminopeptidase and $\beta$-glucosidase are produced but not alkaline phosphatase, chymotrypsin, $\alpha$-fucosidase, $\alpha$ - or $\beta$-galactosidase, $\beta$-glucuronidase, $N$ acetyl- $\beta$-glucosaminidase, $\alpha$-mannosidase, trypsin or valine aminopeptidase. Degrades Tween 20 but not adenine, casein or elastin. Pyruvate is used as a sole carbon source but not arabinose, fructose, galactose, maltose, mannose, melezitose, rhamnose, salicin or sorbitol (all at $0 \cdot 1 \%, w / v$ ) or acetamide, benzamide, benzoate, butyrate, citrate, $p$-cresol, gluconate, $m$ - or $p$-hydroxybenzoic acid, lactate, malate, octanoate, oxalate, pimelate, propionate, sebacate, succinate, tartrate, testosterone or tyrosine (all at $0.01 \%, \mathrm{w} / \mathrm{v}$ ). Grows from pH 5 to 8 and between 15 and $30^{\circ} \mathrm{C}$, albeit weakly at these latter temperatures. Does not grow in the presence of crystal violet $(0 \cdot 001 \%)$, phenol $(0 \cdot 01 \%, \mathrm{w} / \mathrm{v})$, phenol ethanol $(0.03 \%, \mathrm{v} / \mathrm{v})$, sodium azide $(0.01 \%, \mathrm{w} / \mathrm{v})$, sodium chloride $(5 \%, \mathrm{w} / \mathrm{v})$ or penicillin (10 IU). Additional phenotypic properties are shown in Table 1. Chemotaxonomic properties are typical of the genus Gordonia. The $\mathrm{G}+\mathrm{C}$ content of the genomic DNA is $63 \cdot 1 \mathrm{~mol} \%$.

The type strain, $\mathrm{J}^{\mathrm{T}}\left(=\mathrm{DSM} 44981^{\mathrm{T}}=\mathrm{NCIMB} 14149^{\mathrm{T}}\right)$, was isolated from a foam sample taken from an activated sludge plant at Brimbank Park, Victoria, Australia.

\section{Acknowledgements}

The authors are indebted to Amanda Jones for her help in preparing the manuscript.

\section{References}

Blackall, L. L., Parlett, J. H., Hayward, A. C., Minnikin, D. E., Greenfield, D. E. \& Harbers, A. E. (1989). Nocardia pinensis sp. nov., an actinomycete found in activated sludge foams in Australia. J Gen Microbiol 135, 1547-1558.

Chun, J., Blackall, L. L., Kang, S.-O., Hah, Y.-C. \& Goodfellow, M. (1997). A proposal to reclassify Nocardia pinensis Blackall et al. as Skermania piniformis gen. nov., comb. nov. Int J Syst Bacteriol 47, 127-131.

Felsenstein, J. (1981). Evolutionary trees from DNA sequences: a maximum likelihood approach. J Mol Evol 17, 368-376.

Felsenstein, J. (1985). Confidence limits on phylogenies: an approach using the bootstrap. Evolution 39, 783-791.

Felsenstein, J. (1989). PHYLIP - Phylogeny Inference Package (version 3.2). Cladistics 5, 164-166.

Fitch, W. M. (1971). Towards defining the course of evolution: minimum change for a specific tree topology. Syst Zool 20, 406-416.

Goodfellow, M. \& Maldonado, L. A. (2006). The families Dietziaceae, Gordoniaceae, Nocardiaceae and Tsukamurellaceae. In The Prokaryotes, 3rd edn, vol. 3, Archaea and Bacteria: Firmicutes,
Actinomycetes. Edited by F. Dworkin, S. Falkow, K. H. Schleifer \& E. Stackebrandt. New York, Berlin \& Heidelberg: Springer (in press).

Goodfellow, M., Davenport, R., Stainsby, F. M. \& Curtis, T. P. (1996). Actinomycete diversity associated with foaming in activated sludge plants. J Ind Microbiol Biotechnol 17, 268-280.

Goodfellow, M., Freeman, R. \& Sisson, P. R. (1997). Curie-point pyrolysis mass spectrometry as a tool in clinical microbiology. Zentralbl Bakteriol 285, 133-156.

Goodfellow, M., Stainsby, F. M., Davenport, R., Chun, J. \& Curtis, T. P. (1998). Activated sludge foaming: the true extent of actinomycete diversity. Water Sci Technol 37 (4-5), 511-519.

Jukes, T. H. \& Cantor, C. R. (1969). Evolution of protein molecules. In Mammalian Protein Metabolism, vol. 3, pp. 21-132. Edited by H. N. Munro. New York: Academic Press.

Klatte, S., Rainey, F. A. \& Kroppenstedt, R. M. (1994). Transfer of Rhodococcus aichiensis Tsukamura 1982 and Nocardia amarae Lechevalier and Lechevalier 1994 to the genus Gordona as Gordona aichiensis comb. nov. and Gordona amarae comb. nov. Int J Syst Bacteriol 44, 769-773.

Kummer, C., Schumann, P. \& Stackebrandt, E. (1999). Gordonia alkanivorans sp. nov., isolated from tar-contaminated soil. Int J Syst Bacteriol 49, 1513-1522.

Lechevalier, M. P. \& Lechevalier, H. A. (1970). Chemical composition as a criterion in the classification of aerobic actinomycetes. Int J Syst Bacteriol 20, 434-443.

Lechevalier, M. P. \& Lechevalier, H. A. (1974). Nocardia amarae sp. nov., an actinomycete common in foaming activated sludge. Int J Syst Bacteriol 24, 278-288.

Lechevalier, M. P., De Bièvre, C. \& Lechevalier, H. A. (1977). Chemotaxonomy of aerobic actinomycetes: phospholipid composition. Biochem Syst Ecol 5, 249-260.

Maldonado, L. A., Stainsby, F. M., Ward, A. C. \& Goodfellow, M. (2003). Gordonia sinesedis sp. nov., a novel soil isolate. Antonie van Leeuwenhoek 83, 75-78.

Mesbah, M., Premachandran, U. \& Whitman, W. B. (1989). Precise measurement of the $\mathrm{G}+\mathrm{C}$ content of deoxyribonucleic acid by highperformance liquid chromatography. Int J Syst Bacteriol 39, 159-167.

Minnikin, D. E., Hutchinson, I. G., Caldicott, A. B. \& Goodfellow, M. (1980). Thin-layer chromatography of methanolysates of mycolic acid-containing bacteria. J Chromatogr 188, 221-233.

Minnikin, D. E., O’Donnell, A. G., Goodfellow, M., Alderson, G., Athalye, M., Schaal, A. \& Parlett, J. H. (1984). An integrated procedure for the extraction of bacterial isoprenoid quinones and polar lipids. J Microbiol Methods 2, 233-241.

Nam, S.-W., Chun, J., Kim, S., Kim, W., Zakrzewska-Czerwinska, J. \& Goodfellow, M. (2003). Tsukamurella spumae sp. nov., a novel actinomycete associated with foaming in activated sludge plants. Syst Appl Microbiol 26, 367-375.

Nam, S.-W., Kim, W., Chun, J. \& Goodfellow, M. (2004). Tsukamurella pseudospumae sp. nov., a novel actinomycete isolated from activated sludge foam. Int J Syst Evol Microbiol 54, 1209-1212.

Pitcher, D. G., Saunders, N. A. \& Owen, R. J. (1989). Rapid extraction of bacterial genomic DNA with guanidium thiocyanate. Lett Appl Microbiol 8, 151-156.

Saitou, N. \& Nei, M. (1987). The neighbor-joining method: a new method for reconstructing phylogenetic trees. Mol Biol Evol 4, 406-425.

Schaal, K. P. (1985). Identification of clinically significant actinomycetes and related bacteria using chemical techniques. In Chemical Methods in Bacterial Systematics, pp. 359-381. Edited by M. Goodfellow \& D. E. Minnikin. London: Academic Press. 
Seviour, R. J. \& Blackall, L. L. (editors) (1999). Microbiology of Activated Sludge. Dordrecht: Kluwer.

Soddell, J. A. (1999). Foaming. In Microbiology of Activated Sludge, pp. 161-202. Edited by R. J. Seviour \& L. L. Blackall. Dordrecht: Kluwer.

Soddell, J. A. \& Seviour, R. J. (1998). Numerical taxonomy of Skermania piniformis and related isolates from activated sludge. J Appl Microbiol 84, 272-284.

Soddell, J. A., Stainsby, F. M., Eales, K. L., Kroppenstedt, R. M., Seviour, R. J. \& Goodfellow, M. (2006). Millisia brevis gen. nov., sp. nov., an actinomycete isolated from activated sludge foam. Int J Syst Evol Microbiol 56, 739-744.

Stackebrandt, E., Rainey, F. A. \& Ward-Rainey, N. L. (1997). Proposal for a new hierarchic classification system, Actinobacteria classis nov. Int J Syst Bacteriol 47, 479-491.

Stainsby, F. M., Soddell, J., Seviour, R., Upton, J. \& Goodfellow, M. (2002). Dispelling the "Nocardia amarae" myth: a phylogenetic and phenotypic study of mycolic acid-containing actinomycetes isolated from activated sludge foam. Water Sci Technol 46 (1-2), 81-90.

Tamaoka, J. (1994). Determination of DNA base composition. In Chemical Methods in Prokaryotic Systematics, pp. 463-470. Edited by M. Goodfellow \& A. G. O’Donnell. Chichester: Wiley.

Uchida, K., Kudo, T., Suzuki, K. \& Nakase, T. (1999). A new rapid method of glycolate test by diethyl ether extraction, which is applicable to a small amount of bacterial cells of less than one milligram. J Gen Appl Microbiol 45, 49-56.

Wayne, L. G., Brenner, D. J., Colwell, R. R. \& 9 other authors (1987). Report of the ad hoc committee on reconciliation of approaches to bacterial systematics. Int J Syst Bacteriol 37, 463-464.

Yamamura, H., Hayakawa, M., Nakagawa, Y., Tamura, T., Kohno, T., Komatsu, F. \& limura, Y. (2005). Nocardia takedensis sp. nov., isolated from moat sediment and scumming activated sludge. Int J Syst Evol Microbiol 55, 433-436. 